\title{
The Mitochondrial DNA Mitotype of Louis XVII (1785-1795?)
}

\section{Gérard Lucotte 1 , Thierry Thomasset², Christian Crépin ${ }^{3}$}

\author{
${ }^{1}$ Institut d'Anthropologie Moléculaire, 75005 Paris, France \\ ${ }^{2}$ Service d'Analyse Physico-Chimique, UTC, 50201 Compiègne, France \\ ${ }^{3} 15 \mathrm{~B}^{\mathrm{d}}$ de la Pierre Blanche, 11000 Carcassone, France
}

\begin{abstract}
We have obtained mitochondrial DNA (mtDNA) sequences from Louis XVII's (1785-1795?) hairs : he was the son of the King of France, Louis XVI (1754-1793) and of Queen Marie-Antoinette (1755-1793). The authenticity of the hairs, which were kept in a medallion, is established by optic and electronic microscopy. Sequences of the hypervariable region 2(HVR2) of mtDNA (extracted from two different hairs) show four mutations : 152C, 194T, 263G and 315.1C. The corresponding mtDNA haplogroup is sub-haplogroup H2. As MarieAntoinette had the same combination of HVR2 mutations, this confirms that Louis XVII is her son.
\end{abstract}

Keywords: Mitochondrial DNA Haplogroup ; Louis XVII ; Mutation in the Hypervariable Region 2

\section{INTRODUCTION}

Louis-Charles (born in 1785) is second son of the King of France Louis XVI (1754-1793) and of Queen Marie-Antoinette (1755-1793). Together with his sister, Marie-Thérèse Charlotte (1778-1851), LouisCharles remained imprisoned during the French Revolution in the Temple (in Paris), where they outlived the death of their parents. Louis-Charles was proclaimed Louis XVII, King of France, immediately after his father's death.

In the present study, we compare mitochondrial DNA (mtDNA) sequences we have obtained from the authentic hairs of Louis XVII with those of his mother (that have been already published (1)), to see if these mtDNA sequences belong to the Habsburg type.

\section{MATERIAL AND METHODS \\ The Hairs}

One of us (C.C.) acquired (from the Bancel found) a medallion containing Louis XVII's lock of hair (Figure 1). Ten hairs of this lock were separated (in sterile conditions) from the rest, after the opening of the medallion; these hairs were used subsequently for DNA extractions.

\section{Microscopy and Elementary Analysis}

These ten hairs were examined in confocal stereoscopic micrography (Figure 2), and by SEMEDX (Philips XL30 model, environmental version), probe Bruker AXS energy dispersive X-ray, PGT system analysis (Spirit model, Princeton gamma technology).

\begin{abstract}
DNA Extraction
All the molecular analyses were realized according to the methodology adopted in our previous study (2) concerning the mitochondrial ancient DNA (a-DNA) sequences of K. W. Naundorff. Genomic DNAs were extracted from the ten hairs, using a standard method (0.5 M EDTA, sarcosyl $20 \%$ and proteinase K 10 $\mathrm{mg} / \mathrm{ml}$ ), and purified using a commercial kit (Nucleospin $^{+}$kit ; Macherey-Nagel, Duren, Germany), in accordance with the manufacturer's instructions (with some modifications).
\end{abstract}

\begin{abstract}
Amplification of the mt-DNA Hypervariable Regions

The mt-DNA sequence intervals for HVRl and HVR2 (Hypervariable Regions 1 and 2) were amplified by PCR with primers F15971 and R16410 and with primers L15 and H484, respectively. For each PCR, the DNA extracts of each hair specimen were amplified in a $12 \mu \mathrm{l}$ reaction mixture : $2 \mathrm{mM} \mathrm{MgCl}_{2}$, $50 \mathrm{mM} \mathrm{KCl}, 10 \mathrm{mM}$ Tris $/ \mathrm{HCl}, \mathrm{pH}=9,0.1 \%$ Triton $\mathrm{X}-100,0.2 \mathrm{mM}$ each dNTP, $0.1 \mu \mathrm{M}$ each primer, and $2.5 \mathrm{U}$ of DNA polymerase (Ampli Taq Gold ; Applied Biosystems, Foster City, CA, USA). The amplifications were carried out with an initial denaturation step at $95^{\circ} \mathrm{C}$ for $6 \mathrm{~min}$, followed by 30 35 cycles at $95^{\circ} \mathrm{C}$ for $1 \mathrm{~min}, 55^{\circ} \mathrm{C}$ for $6 \mathrm{~min}$, and $72^{\circ}$ for $1 \mathrm{~min}$.
\end{abstract}

This article is published under the terms of the Creative Commons Attribution License 4.0

Author(s) retain the copyright of this article. Publication rights with Alkhaer Publications.

Published at: http://www.ijsciences.com/pub/issue/2015-11/

DOI: $10.18483 /$ ijSci.865; Online ISSN: 2305-3925; Print ISSN: 2410-4477 


\section{HVR1 and HVR2 DNA sequences}

PCR products were purified from agarose gel (QIAQuick PCR purification kit ; Qiagen, Valencia, CA, USA). Both strands of the amplified mt-DNA fragments removed from agarose gel slides were directly sequenced (Big Dye Terminator Cycle sequencing kit ; Applied Biosystems) and separated (ABI PRISM 3130 Genetic Analyzer ; Applied Biosystems).

The sequences obtained were aligned on the Revised Cambridge Reference Sequence (3), to identify the presence of mutant sites. Seqscape software (Applied Biosystems) and Clustal Analysis (http://www.clustal.org) were used for pairwise alignments.

\section{RESULTS}

Table 1 summarizes the main microscopy characteristics of the ten hairs studied. The following illustrations concern hair number 1 , taken as an example.

Figure 3 shows an optical microscopic view of the hair ; it is blond in colour. Even by transillumination, we cannot see any aspect of the medullar canal inside (a characteristic of fine hairs). All the other hairs are blond in colour, except for hair number 9 that is blond-brown and hair number 10 that is brown-clear. Hair number 5 is apparently white, because of a white deposit covering all the hair surface.

Photography of Figure 4 shows a portion of the hair. Scales at its surface are well-formed ; the mean distance separating each scale-rank is about $5-10 \mu \mathrm{m}$ $(\mu)$, a characteristic of hairs of human origin.

The corresponding EDX spectrum shows an elementary composition characteristic of hair : it is mainly constituted of organic matter (carbon, oxygen, with a very small peak of nitrogen); there is a peak of sulphur (that of keratin). There are also some traces of sodium and chlorine (corresponding to sweat, $\mathrm{ClNa}$ ), and a small peak of potassium.

Photography of Figure 5 shows another MEB view, enlarged, of a part of this portion of hair. The scales are finely preserved and separated, with very few deposits at the surface; the corresponding hair is very clean, being previously well washed and cleaned.

The thickness of hair number 1 in its middle part is $45 \mu$. The mean thickness of all the ten hairs is 41.74 $\mu$, that corresponds to very thin hairs ; the thinnest hair is hair number $2(29 \mu)$.

All the other hairs show the typical EDX spectrum of hair that is shown in Figure 4, but with various heights of sulphur and potassium peaks among the cases.

Most white deposits at the scale surfaces of hair number 1 are micro-needles (Figure 6), separated or lumped in packs, whose elementary compositions are rich in potassium and in sulphur. This corresponds probably to some form of potassium sulphate, a product that was used for hair protection and conservation.

Some hairs have few (hairs number 1, 8 and 10), very few (hair number 2), or no (hairs number 3, 4 and 9) potassium sulfate particles at the surface. These micro-particules vary in form and size (rounded, with angular contours, needles...). In most hairs, the white matter is concentrated at the limits of the scale ranks. Hair number 5 is peculiar in the sense that the white matter covers all the surface (so scales are not visible) and the hair colour is completely white. There are large plates of white matter at the surface of hair number 6 , but the original blond colour of the hair is visible.

Hair number 1 is cut (obliquely, abruptly with a plane haircut) at both of the extremities. It is the same for all the other hairs ; so , they correspond to cut-hairs. Hairs number 9 and 10 correspond to hair point zones ; a hair point is effectively observed for one extremity of hair number 2 .

We have not found any bulb. But the fact that we observed well-formed scales at the surface of the less thiner hairs let us confident about the obtaining of genomic DNA (at least of mtDNA) from some of these hairs.

\section{Results on mtDNA HVR1 and HVR2 sequences.}

We extracted genomic DNA from each of the ten hairs, separately. We were not able to obtain DNA from hair numbers 2, 5-10 ; probably hair numbers 2 , 9 and 10 are too thin, and hair numbers 5 and 6 too covered by potassium sulphate.

We obtained legible DNA sequences (from 16025 to 16359 and from 66 to 304 respectively) of the HVRI (16032- 16352) and HVR2 (72-294) segments of the mtDNA extracted from hair number 1 . No mutations are present in the $H V R 1$ sequence ; but there are four mutations (152C, 194T, 263G and 315.1C) in the HVR2 sequence.

Only the HVRI segment was amplified for hair number 3, with no mutations in it. Concerning hair number 4 , where the two segments were amplified, we found no mutations in HVRl and the four previous mutations in $H V R 2$. So, results obtained from hair numbers 3 and 4 confirm, partially or completely, those obtained from hair number 1 .

In the European system of nomenclature (4), the 152C, 194T, 263G and 315.1C combination 
corresponds to the mtDNA haplogroup $\mathbf{H}$, subhaplogroup $\mathbf{H 2}$.

\section{DISCUSSION}

Our microscopic investigations concerning hairs in the medallion shows that they are all cut-hairs ; so they must correspond to cut hairs used as relics, coming from original longer hairs. These hairs are very thin, indicating hairs of a child. Moreover, these hairs are blond in colour. We know (by the literature and the portraits) that Louis XVII was a young child with long and blond hair.

We have established and confirmed that the hairs in the medaillon have the 152C, 194T, 263G and 315.1C mutations in the HVR2 sequences of their mtDNAs. It was published previously $(\mathbf{1}, \mathbf{5}, \mathbf{6})$ that the hairs of Marie-Antoinette, Louis XVII's mother, had the same HVR2 mutation repertoires than those found here (Table 2) ; because mtDNA is a maternally -transmitted, it is so perfectly possible that the medallion hairs are those of Louis XVII.

The present day living Queen Anna of Romania, a maternal relative of Marie-Antoinette, had also the same repertoire of $H V R 2$ mutations defining that is called the "Habsburg mitotype", and it is also the case for the putative heart of Louis XVII (5).

In conclusion, microscopic studies show that the cut hairs preserved in the medallion we studied could be those of Louis XVII. Molecular analysis established that the mtDNA haplogroup (determined by mutations in the HVR2 segment) coming from genomic DNA extracted from these hairs is identical to that of Marie-Antoinette, Louis XVII's mother. We could now compare this haplogroup to the one belonging to Karl Wilhelm Naundorff (1785?-1845), who pretended to be the son of Louis XVI and MarieAntoinette (2).

List of abbreviations.

a-DNA : ancient DNA ; mtDNA : mitochondrial DNA ; HVRl : HyperVariable Region 1 of the mtDNA ; HVR2 : HyperVariable Region 2 of the
mtDNA; $\mathbf{H}$ : the most common mtDNA haplogroup ; H2 : an H sub-haplogroup ; PCR : Polymerase Chain Reaction ; SEM-EDX : Scanning Electronic Microscopy - Energy Dispersive X-rays.

\section{Acknowledgements.}

We thank Dr S. Leguiner-Lebeau (IGNA of Nantes) for her initial help in detecting HVRI and HVR2 mtDNA Louis XVII's hair sequences. We thank K. Leonhardt, D. Serra and M. Guiette for financial support. This study was included in our program of genetic investigations developed at the Institute of Molecular Anthropology concerning royal families in France.

Additional information : The HVRl and HVR2 mtDNA sequences of Louis XVII's hairs are also available on demand at : lucotte@hotmail.com.

\section{References}

1) Jehaes E, Decorte R, Peneau A, Petrie JH, Boiry PA, Gillissen A, Moisan JP, Van den Berghe H, Pascal O, Cassiman JJ. Mitochondrial DNA analysis on remains of a putative son of Louis XVI, King of France and MarieAntoinette. European Journal of Human Genetics, 1998, 6 : 383-395.

2) Lucotte G, Crépin C, Thomasset T, Paris M. Mitochondrial DNA sequences of the famous Karl Wilhelm Naundorff (1785?-1845). International Journal of Sciences, 2014, 3 : 28-36.

3) Andrews RM, Kubacha J, Chinnery PF, Lightowlers RN, Turnbull DM, Howel N. Reanalysis and revision of the Cambridge reference sequence for human mitochondrial DNA. Nature Genetics, $1999 ; 23: 147$.

4) Brandstätter A, Niederstätter H, Pavlic M, Grubwieser P, Parson W. Generating population data for the EMPOP database - An overview of the mtDNA sequencing and data evaluation processes considering 273 Austrian control region sequences as example. Forensic Science International, 2007, $166: 164-175$.

5) Jehaes E, Pfeiffer H, Toprak K, Decorte R, Brinkmann B, Cassiman JJ. Mitochondrial DNA analysis of the putative heart of Louis XVII, son of Louis XVI and Marie-Antoinette. European Journal of Human Genetics, 2001, 9 :185-190.

6) Jehaes E, Toprak K, Vandrheyden N, Pfeiffer H, Cassiman JJ, Brinkmann B, Decorte R. Pitfalls in the analysis of mitochondrial DNA from ancient specimens and the consequences for forensic DNA analysis : the historical case of the putative heart of Louis XVII. International Journal of Legal Medicine, 2001, 115 : 135-141.

Table 1. Microscopic characterizations of the ten hairs.

\begin{tabular}{|c|c|c|c|c|c|}
\hline Numbers & Colour & $\begin{array}{l}\text { Thickness } \\
(\mu) \text { in the } \\
\text { middle part }\end{array}$ & $\begin{array}{l}\text { Cut ends at } \\
\text { both } \\
\text { extremities }\end{array}$ & $\begin{array}{ll}\text { Well kept } \\
\text { scales }\end{array}$ & $\begin{array}{l}\text { Covered by } \\
\text { potassium } \\
\text { sulfate } \\
\text { particles }\end{array}$ \\
\hline 1 & blond & 45 & yes & yes & few \\
\hline 2 & blond & 29 & $\begin{array}{l}\text { One cut, and } \\
\text { one point }\end{array}$ & yes & very few \\
\hline 3 & blond & 47.5 & yes & yes & no \\
\hline 4 & blond & 46.5 & yes & yes & no \\
\hline 5 & white & 49.7 & yes & not visible & $\begin{array}{l}\text { very } \\
\text { numerous }\end{array}$ \\
\hline
\end{tabular}




\begin{tabular}{|l|l|l|l|l|l|l|}
\hline $\mathbf{6}$ & blond & 52 & yes & yes & numerous & \\
\hline $\mathbf{7}$ & blond & 38.3 & yes & yes & no & \\
\hline $\mathbf{8}$ & blond & 42.3 & yes & yes & few & \\
\hline $\mathbf{9}$ & blond-brown & 34.1 & yes & yes & no & \\
\hline $\mathbf{1 0}$ & brown-clear & 33 & yes & yes & few & \\
\hline
\end{tabular}

Table 2. Consensus mtDNA HVR2 sequences obtained from different samples (mutated bases are indicated in italic).

\begin{tabular}{|l|l|l|l|l|l|l|}
\hline & \multicolumn{5}{|c|}{ HVR2 } & \multicolumn{5}{|c|}{ References } \\
\hline $\begin{array}{l}\text { Origin of } \\
\text { the samples }\end{array}$ & $\begin{array}{l}\text { Tissue } \\
\text { samples }\end{array}$ & $\mathbf{1 5 2}$ & $\mathbf{1 9 4}$ & $\mathbf{2 6 3}$ & $\mathbf{3 1 5 . 1}$ & \\
\hline Louis XVII & hairs & $C$ & $T$ & $G$ & $C$ & Present study \\
\hline $\begin{array}{l}\text { Marie- } \\
\text { Antoinette }\end{array}$ & hairs & $C$ & $T / C$ & $G$ & $C$ & $\mathbf{( 1 )}$ \\
\hline $\begin{array}{l}\text { Anna of } \\
\text { Romania }\end{array}$ & blood & $C$ & $T$ & $G$ & $C$ & $(\mathbf{5})$ \\
\hline
\end{tabular}

Figure 1. Above: The medallion face, after glass-covering removal, showing (arrow) the lock of hair. Below : The other medallion face, with the portrait of Louis XVII.
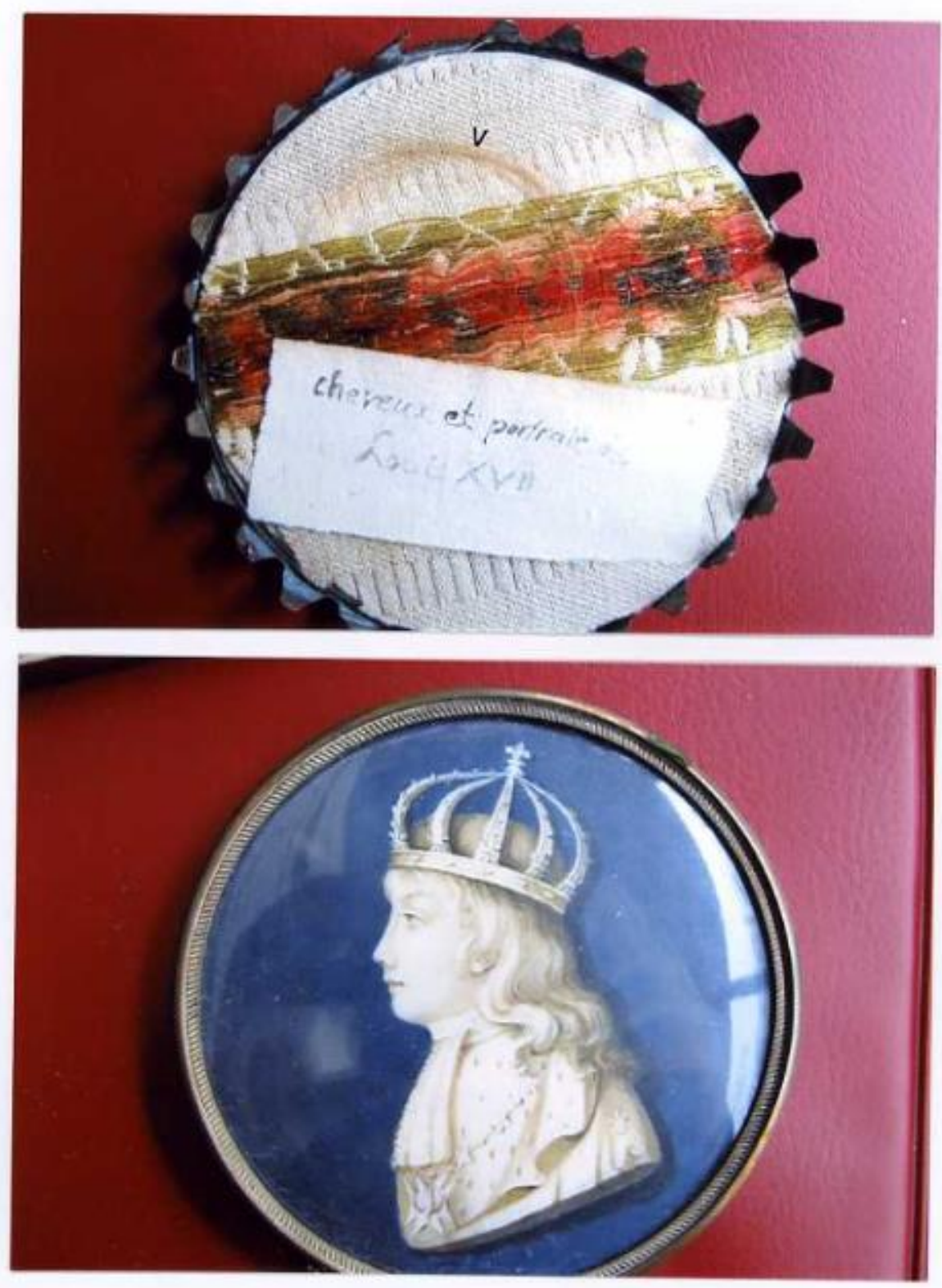
Figure 2. A synthetic view of the ten hairs (numbered 1 to 10), seen in optical microscopy ( $\mathrm{v}$ : a little vegetable fragment).

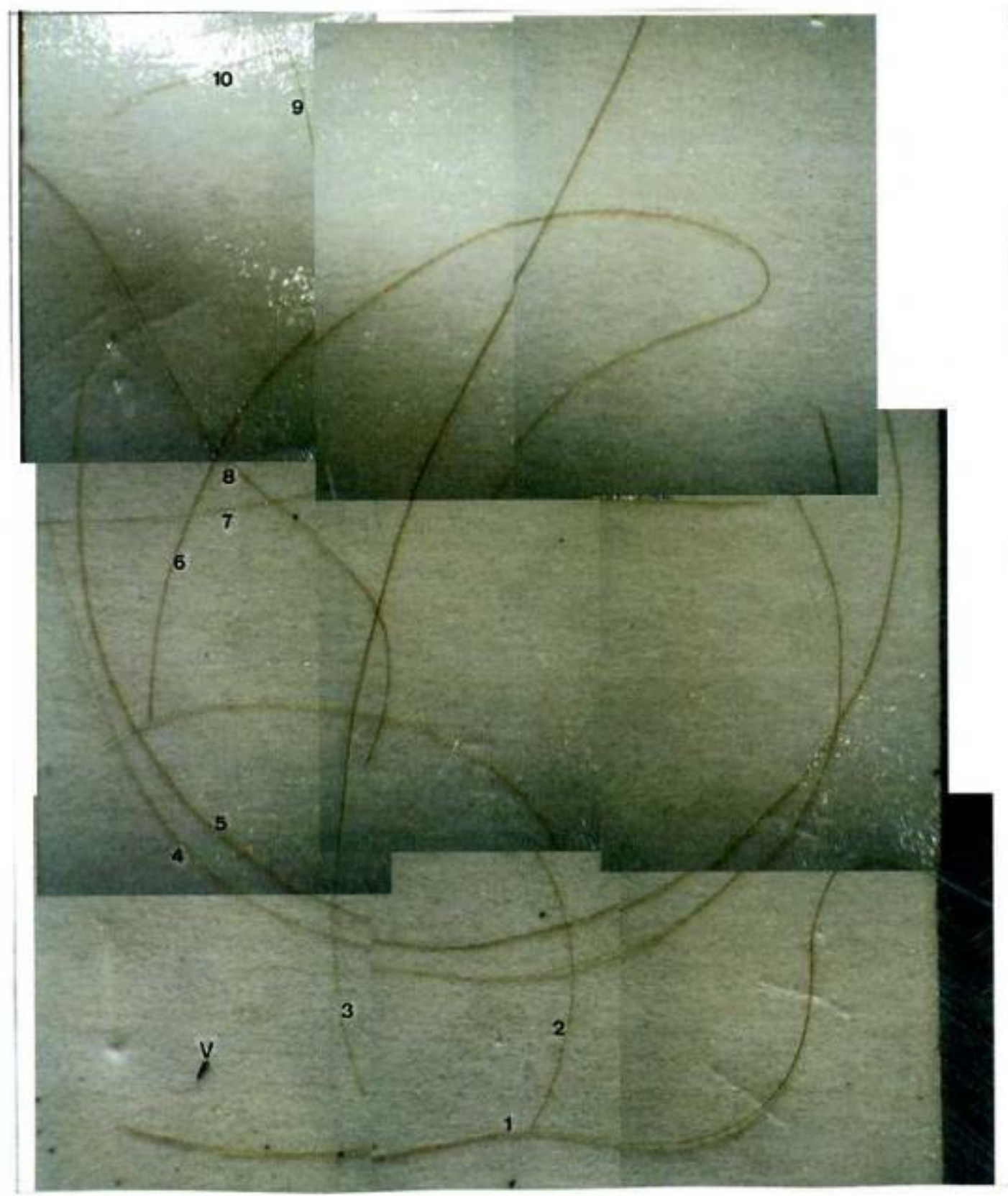


Figure 3. Optical view (x50) of a portion of hair number 1.

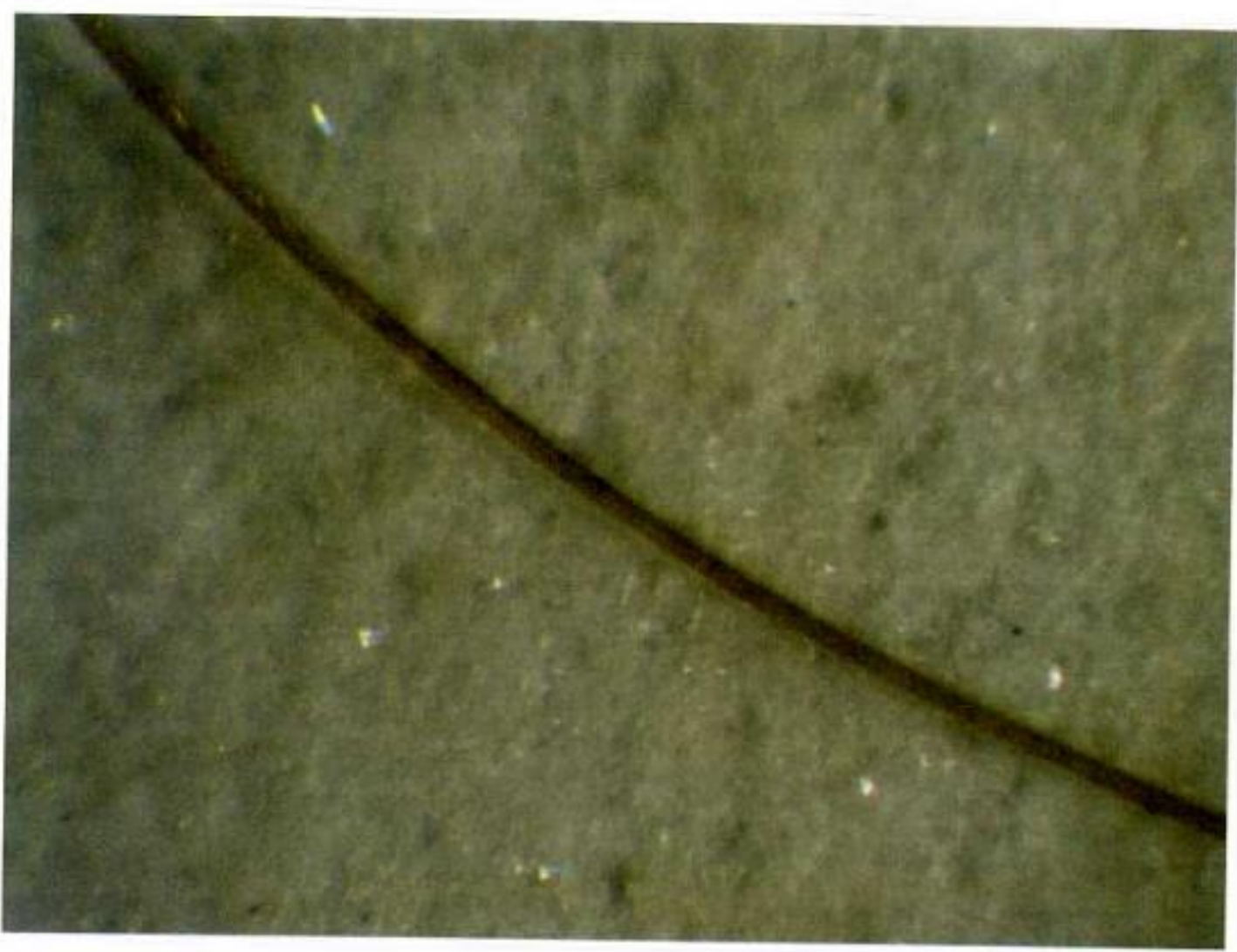


Figure 4. Above : a MEB photography (x2000) of a portion of the hair, in its middle part (m : mycelium filaments). Below : EDX-spectrum taken at the back point indicated. $\mathrm{C}$ : carbon, $\mathrm{N}$ : nitrogen, $\mathrm{O}$ : oxygen, Na : sodium, $\mathrm{S}$ (two peaks) : sulphur, $\mathrm{Cl}$ : chlorine, $\mathrm{K}$ (two peaks) : potassium.

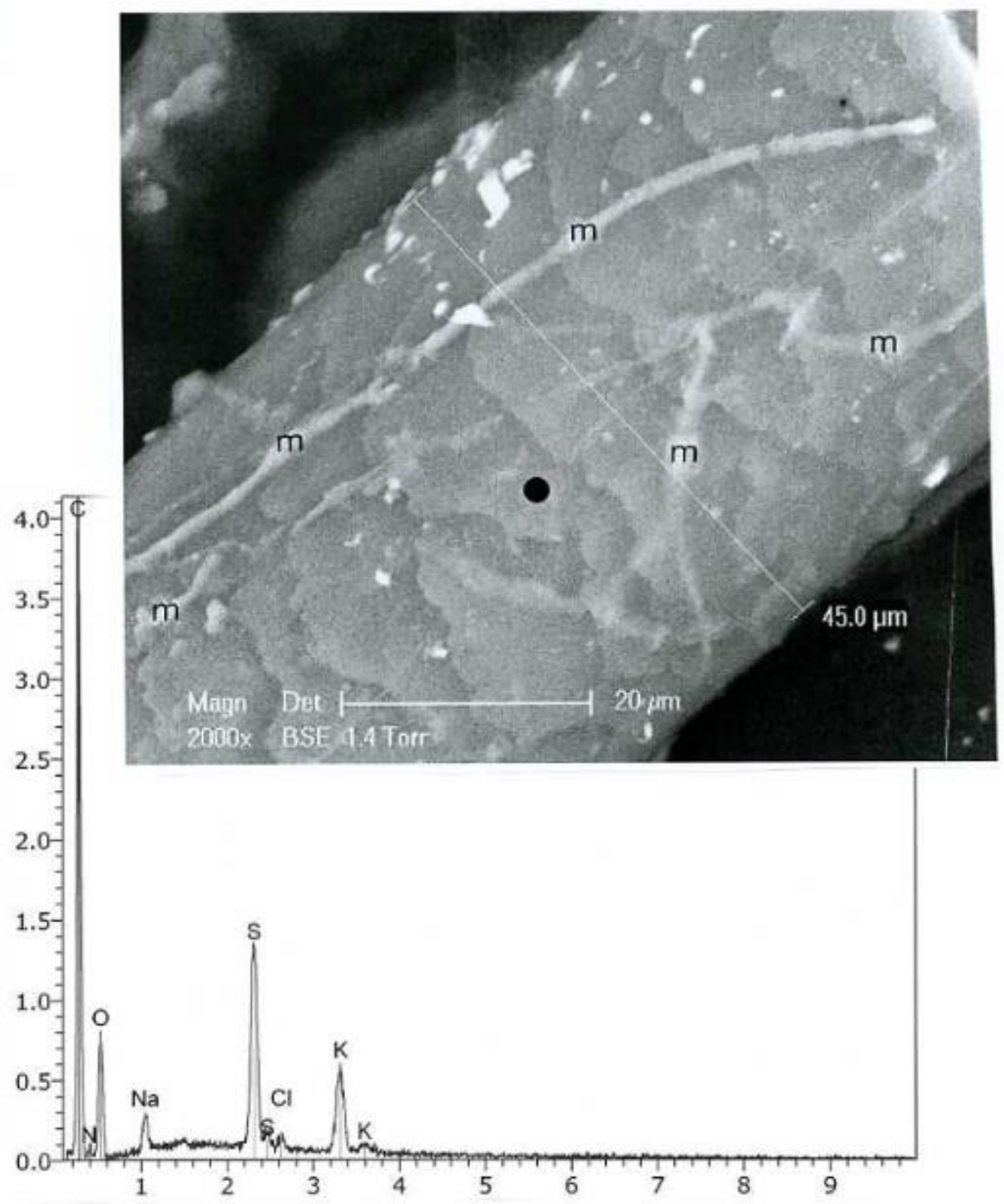


Figure 5. A MEB enlarged (x4000) view of the scales.

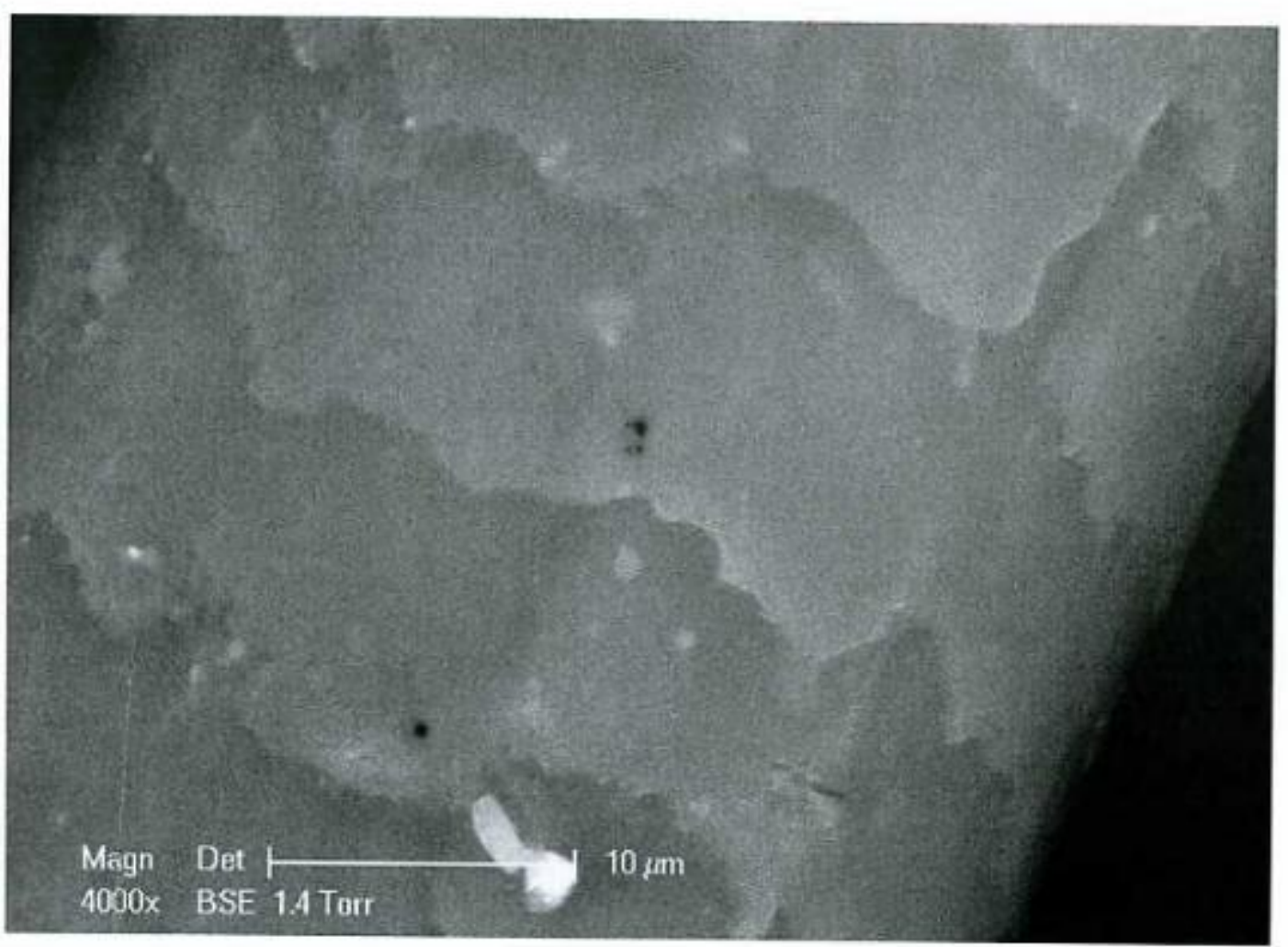


Figure 6. Above : MEB photography (x2000) of the micro-needles deposited at some part of the surface of hair number 1. Below: the corresponding spectrum.
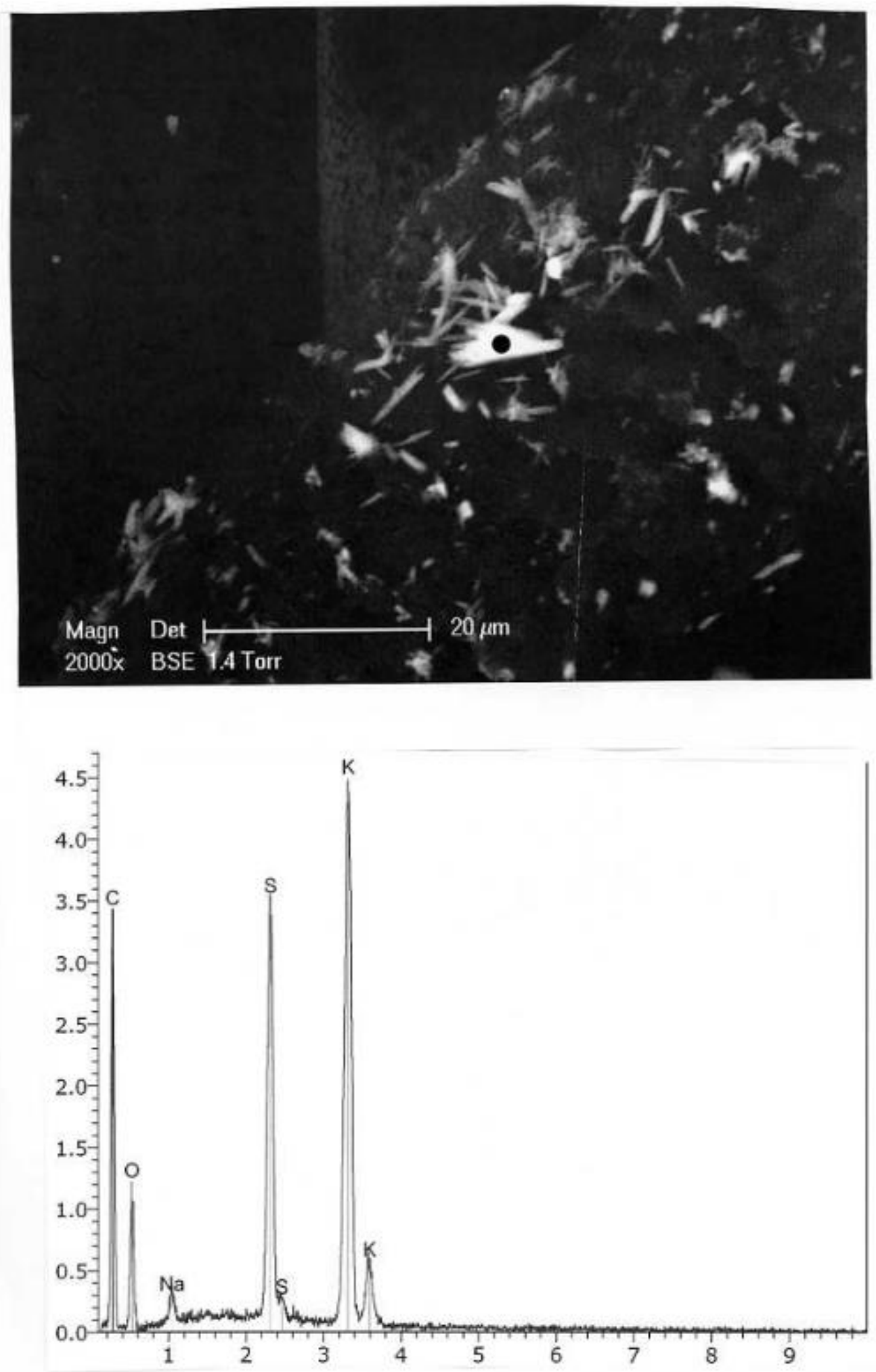